\title{
Kate Rousmaniere Citizen Teacher: The Life and Leadership of Margaret Haley.
}

Albany: State University of NewYork Press, 2005. xi + 271 pp.

\section{John G. Reid}

Saint Mary's University

This is an engaged biography. From the beginning, Kate Rousmaniere makes it clear that she sees much in the principles for which Margaret Haley fought a century ago that could and should be vigorously reintroduced into current debates over educational issues in the United States. For Haley, a Chicago elementary school teacher who emerged during the first decade of the twentieth century as a teachers' leader of national stature, "the public school was the heart of democracy and ... teachers were its life blood" (ix). Haley resisted any suggestions that the professionalism of teachers should imply standing apart from political and economic activism. Rather, she believed, teachers as citizens should not only defend their own well-being through union affiliation, but also take aim politically at corporate interests that damaged public education through tax avoidance. Always hewing to the progressivist rather than the socialist side of the ideological divide among reformers of the era, Haley - who was fond of military metaphors and wrote an autobiography aptly entitled Battleground nevertheless took a "ferocious" (212) approach against the male elites of corporations, political institutions and the education system. "It is time," Rousmaniere argues in this vivid biographical study, "to bring Margaret Haley's vision of civic activism and teacher leadership back to the forefront of educational work" (215).

Margaret Haley was born to Irish-American parents in a small town near Joliet, Illinois, in 1861. Her father was a canal labourer who went on to become a stonecutter and then a contractor. The family, she later recalled, was supportive, harmonious and apparently economically secure. However, a series of disasters intervened during the 1870s, including the deaths of two siblings and the collapse of her father's business. Sixteen-year-old Margaret, now the eldest child, had no choice but to start teaching as a way of supplementing the family income. Although she quickly came to love her work, 
the way in which she began her career implanted a strong awareness of social class that combined with the ethnic and Catholic sensibilities she derived from her father's involvement in Irish nationalist organizations. Moving to Chicago in the early 1880s, she spent sixteen years in a crowded sixth-grade classroom on the city's working-class south side. Haley was skeptical of the "ethos of self-sacrifice" (36) that surrounded women teachers, and her move into the leadership ranks of the Chicago Teachers' Federation (CTF) in 1898 marked her emergence as an activist.

For almost four decades thereafter, until poor health restricted her activities in the mid-1930s, Margaret Haley waged campaign after campaign on behalf of the teachers she sought to politicize. From 1900, this became her full-time occupation, and her "most public accomplishment" (93) was reached in 1902 with the affiliation of the CTF with the American Federation of Labour. She always struggled to ensure that public education should receive its due from reluctant moneyed and corporate taxpayers. Soon she was a national figure, who in 1913 was able to gain immediate access to President Woodrow Wilson to lobby against the granting of a federal appointment to one of her political opponents. Her priority, however, was always to represent the teachers who were her local constituents, a task she preferred over indulging wider personal ambitions or involving herself with worthy but competing issues. For example, she was sympathetic to suffragism but never a consistent campaigner in that cause. Her single-mindedness also, however, led her into avoidable conflicts with other teachers' groups and with potential allies such as the social reformer, Jane Addams, with whom she collaborated uneasily at times but referred to sarcastically as "Gentle Jane" (140). During the 1920s, her credibility was undercut by tensions with younger teachers unionized through the American Federation of Teachers (AFT), and the CTF gradually shrank to becoming "a surviving cohort of elderly Irish American women elementary teachers" (203). Still active on educational issues until 1935, Haley then declined into poverty and, possibly, dementia. Following her death in 1939, her estate consisted of $\$ 25.00$ and her manuscript autobiography (208).

As a biographical subject, Haley is in many respects a complex and - despite her public prominence - an elusive figure. Rousmaniere deals admirably with the challenges involved in assessing her life and career. Evidence of Haley's private life was scarce. Few personal papers have survived. Her autobiographical writings, while dealing at length with her political activities, were designed to reveal "as little of my own personality as is humanely $[$ sic $]$ possible" (quoted, 254). She was, Rousmaniere comments, "never a particularly self-reflective person" (30). Despite this limitation, the book is convincing in delineating Haley's character and motivations. While there is no firm evidence of close personal relationships outside of her family, her younger sister Eliza was a lifelong domestic, professional and political partner. Her circle of friends, wide and often boisterous as it was, consisted largely of fellow activists. In effect, "Haley's private life was her public life" (167; emphasis in original). So much was this so that her very persona was shaped by her need "to carefully walk the line between radical unionism and social welfare, between the self-preservation that was allowed for masculine and working-class workers, and the concern for others that was expected of women and 
white-collar workers" (58). Always alert to the political advantages of disclosing in herself elements of traditional femininity, she nevertheless made devastatingly effective use of humour, dramatic and passionate oratory, and, most of all, the ability to transform herself at will into a pugnacious, combative "political animal" (78).

Rousmaniere makes it clear; Margaret Haley's strengths were also her weaknesses. Her Irish-American cultural grounding fostered a lifelong ambivalence towards AfricanAmericans that was duly reflected at times in positions taken by the CTF. The CTF itself might have gained a larger and more diverse membership had it not been for Haley's reluctance to reach out to African-American elementary school teachers. More pervasively, Haley's uncompromising political style came at a price. Never good at making strategic concessions or acknowledging the work of allies, she increasingly turned on other reformers and competing educational organizations the aggression that had been so effective against the members of the male establishment who were her more natural opponents. Always capable of being "brusque and bossy" (85), Haley was ultimately characterized by a "corrosive leadership style" (198) that clearly restricted her constituency during her later years.

Rousmaniere concludes that these failings were partly responsible for "the resounding failure of all of Haley's propositions" (213). However, the strength of the political and corporate forces ranged against her, was also critical. Thus, she was "a visionary leader who was also a tragic figure bowled over by forces greater than herself and by the political complexities of her time and her profession" (213). Yet, even admitting that Haley fell short of conclusive success in her extended campaigns, it is debatable whether the book shows her to have been bowled over by anybody or anything. Rather, it is the considerable achievement of Rousmaniere's fine study that Haley emerges as a crucial transitional leader whose style and approach were eventually overtaken by the rise of the AFT - which in 1916 rejected her candidacy to be its founding president - but who had continually broken new ground through her unabashed and single-minded activism. Rousmaniere makes a persuasive case that Haley's vision may yet have the power to "inspire contemporary educators" (xi). At the very least, the book has succeeded notably in capturing, as all biographies must, the essence of an individual life, while also showing clearly how and where Margaret Haley belongs in our understanding of a momentous period of educational and social change. 